\title{
Do Family-Owned Banks Perform Better? A Study of Malaysian Banking Industry
}

\author{
Tze San Ong ${ }^{1} \&$ Shih Sze Gan ${ }^{1}$ \\ ${ }^{1}$ Faculty of Economics and Management, University Putra Malaysia, Malaysia \\ Correspondence: Tze San Ong, Department of Accounting and Finance, Faculty of Economics and Management, \\ Universiti Putra Malaysia, 43400 UPM Serdang, Selangor, Malaysia. Tel: 60-3-8946-7571. E-mail: \\ tzesan@econ.upm.edu.my; tzesan1108@gmail.com
}

\author{
Received: February 21, 2013 Accepted: March 26, 2013 Online Published: June 1, 2013 \\ doi:10.5539/ass.v9n7p124 URL: http://dx.doi.org/10.5539/ass.v9n7p124
}

\begin{abstract}
It has been discussed that whether family ownership perform better or less perform than non-family ownership that might create or destroy agency costs among the managers and shareholders. This paper is to investigate the financial performance of family and non-family owned banks in Malaysia from year 2001 to 2010. This study compares the financial performance of family and non-family owned banks that operate under central bank of Malaysia, (BNM) and are listed on Bursa Malaysia. Multiple regression technique was performed to investigate the relationship between independent variable (ownership structure) and dependent variables (Tobin's Q, ROA and ROE). Findings indicate that Tobin's $\mathrm{Q}$ is the best fit as the dependent variable for the regression model. It shows the highest $\mathrm{F}$ statistics value, which is 6.247 as compared to ROA and ROE for full sample. Meanwhile, the adjusted R squared of Tobin's Q indicates similar higher value as well that is 0.150 between the dependent variables. Board composition and board size indicate strong influence on the performance of family-owned banks. Smaller board size on the board can help the bank to achieve better performance in term of Tobin's Q and ROE. In contrast, board composition attains better performance in term of ROA rather than Tobin's Q and ROE. This study can provide useful insights of the governance mechanism that could influence the firm performance.
\end{abstract}

Keywords: family ownership, agency theory, Tobin's Q, Malaysia domestic commercial banks

\section{Introduction}

Family-owned firms are relatively common among public-listed firms in many countries. In fact, family-owned firm is the most fundamental business form of organizational structure around the world (La Porta, Lopez de Silanes \& Shleifer, 1999). To some, the family-owned firm is still perceived to be the main agent of economic progress and driver of the British economy (Amoore, 1995). In this standpoint, family-owned firm is significantly important for business governance structure in both developed and developing countries due to positive outcomes on local economic development. In Europe, family businesses approximate contribute between 30-60 percent of gross domestic product (GDP) to the local economic development (IFERA, 2003). In United State (U.S), family-owned firms account for nearly 90 percent of incorporated business (Poza, 2007) and one third of the S\&P 500 companies (Anderson \& Reeb, 2003). In developed countries, new startup of family-owned business has become an important key success component to generate employment rate and thus accelerate economic and technological growth respectively (Astrachan et al, 2003).

In Malaysia, family businesses are reported to contribute more than half of the Malaysian's gross domestic product (GDP) (Ngui, 2002). In other words, family firms become an essential part to accelerate Malaysian economy growth. Besides that, prior study had documented that family-owned firms have accounted approximate 80 percent of the total companies listed on Bursa Malaysia (formally known as Kuala Lumpur Stock Exchange, KLSE) (Sooi, 2003).

Despite their considerable presence among publicly traded companies, family-owned firms are distinct. Many family-owned corporations have both a large stake of equity as well as senior management positions in their firms. In other words, both ownership and control is not separated in these firms. Thus, a family-owned firm is different from the well-known "Berle and Means firm", where ownership is dispersed among small shareholders, but control is concentrated in professional managers. This distinction has lead to different management styles, level of motivation among founders, family values and decision making process (Gomez-Mejia, Tosi \& Hinkin, 
1987; Whisler, 1988; Daily \& Dollinger, 1992; Chua, Chrisman \& Chang, 2003).

Over the past decades, there have been a considerable number of studies conducted on mitigating agency costs between managers and shareholders in the "Berle and Means firm". In contrast, there have been few studies conducted on family-owned firms. However, it is important to study family-owned firms because they are common among public firms both in developed countries as well as developing countries (Anderson \& Reeb, 2003; La Porta et al., 1999)

For many shareholders, the crucial question is whether family owned corporations lead to better or poorer performance. After reviewing studies in Europe, Donckels and Frohlich (1991, p.160) concluded that "there is as yet no answer to the question. Are family businesses better performers than non-family firms or not?". Some perceive family ownership to be detrimental to the corporation as the family owners may pursue not maximize profits and enhance shareholder value (Fama \& Jensen, 1985). For example, the prime objectives of family owned companies are to maintain/ enhance the lifestyle of the owners and to provide employment for family members in the management team (Westhead \& Cowling, 1997). On the other hand, others assert that because their wealth is intrinsically tied to the well-being of the firm, family-owned firms performed better than comparable non-family owned firms (Anderson \& Reeb, 2003; Villalonga \& Amit, 2006). Furthermore, in Asia where corporate transparency is low, family ownership corporations are able to expropriate minority shareholders (Faccio et al., 2001).

The ownership structure of companies is defined by the distribution of equity with regard to votes, capital, and the identity of the equity owners. These structures are of major importance in corporate governance because they determine the incentives of managers and thereby the economic efficiency of the corporations they manage. (Jensen \& Meckling, 1976; Holderness, Kroszner \& Sheehan, 1999). The types of ownership structure has been shown to influence the size and composition of the board of directors (Eldenburg, Hermalin, Weisbach \& Wasinska, 2004), which in turn, is inversely correlated to firm performance. Larger board size tends to utilize their assets less efficiency and thus earn less profits indeed (Yermack, 1996).

According to Jensen (2000), ownership structure is an important element to identify firm's objectives in order to maximize shareholders' value and control discipline of managers. Maximizing firm value is one of the significant goals that managers and shareholders should accomplish together. Basically, ownership structure is divided into two different categories such as widely-held firms and controlling-owners firms (Shleifer \& Vishny, 1986; La Porta et al., 1999; Claessens et al., 2000; Faccio \& Lang, 2002; Anderson \& Reeb, 2003). For widely held businesses, it means that owners do not have any significant control right over the management. On the other hand, concentrated owners firms can be classified into four distinct categories such as widely held businesses, widely held financial agencies, family-owned firms and government-owned firms (Claessens, Djankov \& Lang, 2000; La Porta \& Lopez-De-Silanes, 1999).

Regarding to family-owned firms performance, it has been received considerable attention in the financial and management literature. For instance, it can be measured in term of profitability, efficiency in portfolio management and operating efficiency. In academic research perspective, family business usually interrelated with entrepreneurial activities where family members tend to have peaceful environment as well as essence of advanced technologies (Astrachen et al., 2003). Some prior research studies have examined the effect of family ownership, family control, founders versus second and subsequent generations related on firm performance (Anderson and Reeb, 2003; McConaughy, Walker, Henderson and Mishra, 1998; Miller, Le Breton-Miller, Lester and Cannella, 2007; Villalonga \& Amit, 2006). However, the findings between family firms and non-family firms' performance were discovered to be mixed in results.

In U.S, empirical studies concluded that family firms are outperform than non-family firms (Aderson \& Reeb, 2003; Miller \& Breton-Miller, 2006; Villalonga \& Amit, 2006). According to Aderson and Reeb (2003), family-owned firms outperformed than non-family firms by 6.65 percent of return on assets (ROA) and return on equity (ROE) and achieved an excess of 10 percent in market performance in the S\&P 500. Meanwhile, several new empirical evidences have been published found that results to be varied in other countries such as Japan (Allouche, Amann, Jaussaud \& Kurashina, 2008), East Asia (Faccio, Lang \& Young, 2001; Filatochev, Lien \& Piesse, 2005), Western Europe (Barontini \& Caprio, 2006; Maury, 2006; Pindado, Requejo \& De la Torre Olvera, 2008) and Eastern Europe (Kowalewski, Talavera \& Stetsyuk, 2010).

In Malaysia, prior literature proved that family ownership experiences higher value than non-family ownership when using ROE, yet does not applicable to Tobin's Q and ROA when using as performance indicators (Samad, Amir \& Ibrahim, 2008). According to Samad et al., (2008), three variables include as governance attribute such as size of board, independent non-executive directors and duality during carries out the research. Similarly, 
Amran and Ahmad (2009) conduct the same study but using different period of dataset. From their studies, family ownership did practice different corporate governance as compared to non-family ownership. Family businesses well proven to practice separate leadership structure and board size that contributes positive relationship towards superior performance than non-family businesses.

Nevertheless, this evidence still open to questions and unconvincing whether family-owned firms outperform than non-family firms. The most apparent contradict data could be explained by difference term of family firms definitions, samples, period of study, variables and methodologies. As overall, studies in investigate on the family firms performance remain less and lack of knowledge in Malaysia context. Thus, this study is focus on examines the relationship between family ownership and non-family ownership and performance in Malaysia domestic commercial banks.

This paper is organized into five parts. The first part consists of introduction and definition of family firms. The second part is literature review then follow by third part which is methodology. The fourth part is presents the findings and results. Last but not least, the final part is conclusion of the study.

\subsection{Definition of Family Ownership}

The most challenge faces by the business researchers is defining family ownership of firms. Many academicians, practitioners and researchers are still concerning the questions what define the most successful or effective of family businesses. From empirical study of Anderson and Reeb (2003), family firm is defines consist either individually or groups of the founder or any close family relationship among the owners, directors or blockholders. According to Astrachan, Klein and Smyrnios (2002), family ownership can be referred as the degree of family presence on the board besides in regard to family power dimension only (Favero, Giglio, Honorati \& Panunzi, 2006; Kowalewski et al, 2010; Maury 2006; Pindado et al, 2008; Sraer \& Thesmar, 2006). Further, Astrachen et al. (2006), describes family business mainly comprises into three major dimensions such as power, experiences and family culture. In precise, family-owned businesscan be explained according to family control and voting rights. Moreover, some prior studies define family firms on a control basis (Adams, Almeida \& Ferreira, 2009; McConaughy et al., 1998) and others through a joint ownership and management criterion (Allouche et. al., 2008; Anderson \& Reeb, 2003; Lee, 2006).

\section{Literature Review}

\subsection{Family Ownership in Malaysia}

In Malaysia, various studies have been carried out on the impact of ownership structure and firm performance. According to Abdul Rahman (2006), most of the established family-owned firms listed in Malaysia are dominant by their family members who intend to appear inherited for their next generations. In addition, prior study by Claessens et al. (2000), firms with highly concentrated of ownership is manages by family founders and their descendants. Moreover, a prior study examines by Mohr Sehat and Abdul Rahman (2005), concentration of ownership is interrelated with direct shareholdings point of view. The study is carry out according to highest 100 Malaysian listed firms based on total market capitalization and assume 5 percent as the cut-off level. The results show significant average 55.84 percent shares are owned by blockholder in every company. Meanwhile, the differences between lowest and highest concentrated ownership is 83.90 percent which is 5.09 percent versus 89 percent respectively. In this standpoint, most of the companies are highly concentrated in Malaysia. Based on past historical record, most of the family corporations are controlled by foreigners' especially European countries after independence (1957). However, older and smaller family-controlled firms do contribute main business form inside the country. Based on World Bank (1999), approximate 85 percent of family-controlled firms are established for the Chief Executive Officer (CEO) position, chairman and owner manager in global.

Prior literature from Daily and Dollinger (1992), family-owned business commonly reflects differences of management styles and strategic structural processes as compared to qualified managed firms. The study further suggests that owned managers who ran the firms usually characterized by centralized decision-making talent as they behave differently from other professional managers. In addition, owned managers and professional managers have different type of strategic and operational planning as both parties have differ goals and objectives. Previous studies from File, Prince and Rankin (1994) and Dunn (1995), family firms tend to perform different priorities on difficult challenge tasks and various goals or objectives rather than non-family firms.

\subsection{Agency Theory}

According toMaijoor (2000), agency theory always interrelated with monitoring mechanisms of governance matters. The principal of separation ownership and management according to agency theory suggests that principal-agent conflict happen due to different interest of both parties as managers may pursue for individual 
interest rather than maximize shareholder wealth (Jersen \& Meckling, 1976; Shleifer \& Vishny, 1986; Ugurlu, 2000). In this standpoint, the interest discrepancy could cause information asymmetry and agency costs between managers and shareholders (Farrer \& Ramsay, 1998). In Asia, prior study has been highlights that agency problem give significant influence on extensive concentrated ownership structure in order to shifts conflicts among family-controlled owners and minority shareholders (Claessens \& Fan, 2002).

There is remains an open questions whether family ownership could provide better incentive to minimize agency costs or create it, still consider an empirical issue. Agency costs can be reduced through several ways suggested by previous studies. One of the most significant to emphasizes here is concentrated shareholdings of family involvement have greater alignment of managerial interests between managers and shareholders through satisfaction of incentive to minimize agency costs. According to Kang (1998), active family members able to monitor their managers' performance and thus create effective flow of information. Prior study by Wang (2006), well-establish of family firms are tends to avoid perform in opportunistic behavior as to protect their family's names and reputations in order to maintain superior performance. Besides that, study by Hashim and Devi (2008), suggests that presence of family members have greater capability to monitor effective firm's operation and activities. This study further supports the argument that family firms attempt to maximize shareholder wealth in order to maintain family's status.

However, some prior literature arises possible consideration of family-owned firms may create agency costs. Based on Bartholomeusz and Tanewski (2006), family members easily misuse their power to expropriate wealth from outside shareholders through unnecessary compensation, transaction of payments and special dividends. In addition, according to Ibrahim and Abdul Samad (2011), family members are more risk averse and concentrate about family interests that could cause less firm value in family firms. In other words, risk avoidant of family members usually invest less risky projects which does not align with other shareholders' interests to maximize wealth.

\subsection{Family Ownership and Firm Performance}

Most of the literature studies on family-owned firms' emphasis on negative impacts of family perspectives and overview this types of organization structure is comparatively unprofitable. A widely theoretical perspective usually related to family ownership is agency problem that results concentrated shareholders to exchange profits from private leases due to combination of ownership and control (Jersen \& Meckling, 1976). For instance, family members may misuse their control to draw scare resources away in order to satisfy their own personal interest or financial compensation (Demstez, 1983).

On the other hand, recent studies highlight that family controlled firms are more valuable and outperform in term of valuations and profitability than non-family firms (Maury; 2006, Barontini \& Caprio, 2006). In these empirical studies, market stock value and profitability are two important proxies to measure performance of a company. Prior evidences reveal that family-owned firms able to perform higher market-to-equity ratio and stock market returns than non-family firms with similar firm size and proportion of managerial ownership (McConaughy, Walker, Henderson \& Mishra, 1998; Ibrahim \& Samad 2011).

However, according to Smith and Amoako-Adu (1999) and Perez- Gonzalez (2002), family firm performance declines significantly when appointed new managers to control family management as a path succeed of family. In general, family ownership likely positive and significant related to firm performance as it could help to reduce agency problem. In other words, family-controlled firms are most significant to align the interest between managers and the owners since both parties have the same goals and objectives (Martinez, Stohr \& Quiroga, 2007; Villalonga \& Amit, 2006; Lee 2004; Anderson \& Reeb, 2003; McConaugby, Mathew \& Fialko, 2001; McConaugby \& Phillips, 1999).

\section{Methodology}

\subsection{Tobin's $Q$}

Tobin's $\mathrm{Q}$ is uses to evaluate performance of an organization in term of market value in financial management aspect. In general, Tobin's Q was recognized by economic theorist James C. Tobin in 1969 as the ratio between the market value and replacement value of the same physical assets. It can be calculated by using formula as stated below:

$$
\text { Tobin's } \mathrm{Q}=\frac{\text { Market value of assets }}{\text { Estimated replacement cost }}
$$

If the value of Tobin's $Q$ is more than 1.0, it shows that market value is higher than company physical assets 
value. This indicates the market value reflects some unrecorded assets of the company. From this aspect, companies are encouraged to invest more in capital because these investments have a higher market value than the price paid for them. In other words, these projects are successful in its investments decision. On the other hand, if the value of Tobin's $Q$ is less than 1.0, it reveals the market value is lower than company physical assets value. This probably could tell that the market value is more likely undervaluing the company.

Based on a study by Caprio (2007), Torbin's Q can be calculated by the following formula.

$$
\text { Tobin's } \mathrm{Q}=\frac{\text { Ownershtp smarket value }+ \text { liabitites }{ }^{5} b 00 k \text { value }}{\text { Assets book value }}
$$

\subsection{Bank Performance}

Performance for a business firm usually refers to the stock price development, profitability and current valuation (Melvin \& Hirt 2005). Thus, performance is a proxy indicator to determine a firm financial or market related performance level that either positive or negative. Mostly, bank performance maybe defined as the reflection of the bank resources used in order to achieve its objectives.

For this research paper is concern, there are two sets of significant indicators to examine the relationship between bank governance and its performance which includes accounting performance and market performance respectively. The accounting performance proxy is uses to represent the profitability ratio such as return on assets (ROA) and return on equity (ROE) (Ong, Teo \& Teh, 2011). In contrast, the second set is representing by market performance which is Tobin's Q.

\subsection{Data Collection and Research Sample}

In this paper, secondary data approach is uses to analyze the governance mechanism and performance in Malaysia domestic commercial banks. . All these relevant information obtained from the respective banks annual reports and financial statements which is available from bank's official website and financial databases such as Datastream and Bankscope. The function of Datastream and Bankscope are the main source of providers that consists comprehensive information for this study. Information related to governance mechanism such as board composition and board size were collected from annual reports. This information requires manually calculation regarding to board of directors of particular banks for years 2001 to 2010.

The sources of sample data are collected over 10 year period horizons from 2001 to 2010. The reasoning from previous research studies is to examine the relationship between governance mechanisms and performance. Thus, the modification of this study is to focuses on investigating family-owned bank and nonfamily-owned banks with performance. This study focuses the domestic commercial banks under supervision of central bank, Bank Negara Malaysia (BNM). There exist two different groups of bank ownership structure such as family-controlled and non-family controlled ownership. Therefore, the research sample of this paper takes into account total population of government-owned commercial banks that listed in Bursa Malaysia.

\subsection{Measures of Variables}

In this section, it is important to clearly clarify each variable according to relevant definitions and method to be used to compute. Two variables to be tested such as return on assets (ROA) and return on equity (ROE) to measure accounting-based of performance whereas Tobin's $Q$ is uses to measure market-based performance respectively. Besides that, several control variables of interest are considered such as board composition and board size. The choice of these variables are consistent with the methods and measurement applied by previous researchers(Anderson \& Reeb, 2003; Gunduz \& Tatoglu, 2003; Barontini \& Caprio, 2005). The list of variables and measures are shown in Table 1 below.

Table 1. List of empirical variables

\begin{tabular}{ll}
\hline Variable & \multicolumn{1}{c}{ Measurement } \\
\hline Tobin's Q & Market Capitalization + Total Debt / Total Assets \\
Return on assets (ROA) & Net income / Total Assets \\
Return on equity (ROE) & Net income / Total Equity \\
Family business & Dummy variable 1 represent family business and 0 for non-family business \\
Board Composition & Total number of independent non-executive directors/ total number of directors \\
Board Size & Total number of directors on board \\
\hline
\end{tabular}




\section{Findings and Results}

4.1 Descriptive Statistics

Table 2. Frequency and percentage for family owned and non-family owned banks

\begin{tabular}{lcc}
\hline Type of ownership & Frequency & Percentage (\%) \\
\hline Family Owned Banks & 40 & 44.44 \\
Non-Family Owned Banks & 50 & 55.56 \\
Total & 90 & 100.00 \\
\hline
\end{tabular}

According to Table 2, the sample size for family owned banks represent 44.44 percent which consists of 40 observations (4 companies) listed in Bursa Malaysia. Meanwhile, non-family owned banks take into account to 50 observations (5 companies) with 55.56 percent of total sample. As overall, the total frequency of the study contributes 90 observations of sample size.

Table 3. Descriptive statistics for full sample, family and non-family from year 2001 to 2010

\begin{tabular}{|c|c|c|c|c|}
\hline \multirow[t]{2}{*}{ Variables } & \multicolumn{2}{|r|}{$\begin{array}{l}\text { Full Sample } \\
\qquad(\mathrm{N}=90)\end{array}$} & \multirow{2}{*}{$\begin{array}{c}\text { Family } \\
(\mathrm{N}=40) \\
\text { Mean }\end{array}$} & \multirow{2}{*}{$\begin{array}{c}\text { Non-family } \\
(\mathrm{N}=50) \\
\text { Mean }\end{array}$} \\
\hline & Mean & Standard Deviation & & \\
\hline \multicolumn{5}{|c|}{ Performance Characteristics } \\
\hline \multicolumn{5}{|l|}{ Market Measure: } \\
\hline Tobin's Q & 0.9086 & 0.1252 & 0.8552 & 0.9514 \\
\hline \multicolumn{5}{|l|}{ Accounting Measures: } \\
\hline Return on assets (ROA) & 0.0368 & 0.0441 & 0.0440 & 0.0310 \\
\hline Return on equity (ROE) & 0.3530 & 0.1486 & 0.3327 & 0.3692 \\
\hline \multicolumn{5}{|c|}{ Governance (Board Structure) Characteristics } \\
\hline Board Composition & 0.4982 & 0.1542 & 0.4616 & 0.5274 \\
\hline Board Size & 9.6889 & 1.8762 & 10.125 & 9.3400 \\
\hline
\end{tabular}

Tobin's $\mathrm{Q}=$ Market value of common equity plus book value of preferred stocks and total debts divided by book value of the total assets,

$\mathrm{ROA}=$ Net income divided by total assets

$\mathrm{ROE}=$ Net income divided by total equity

Board Composition $=$ Total number of independent non-executive directors divided by total number of directors

Board Size $=$ Total number of directors on the board

Table 3 shows the descriptive statistics for full and individual sample of domestic commercial banks in Malaysia. In general, it reports the means values of these independent and dependent variables between family and non-family ownership. For market measure of firm performance, Tobin's Q indicates that non-family has better valuation than family ownership. The average value of Tobin's $Q$ for non- family ownership is 0.9514 versus 0.8552 for family ownership respectively.

Besides that, this study includes financial measures of firm performance as well such as return on assets (ROA) and return on equity (ROE) respectively. For return on assets, the average value of total assets is RM 145,805 million for overall sample. In precise, average total assets of family contribute smaller value than non-family which is RM 138,847 million relative to RM 151,371 million. This results show similar interpretation with other prior literature on investigating relationship between family and non-family and performance (Sraer \& Thesmar, 2006; Favero et al., 2006; Amit \& Villalonga, 2006; Barontini \& Caprio, 2005; Anderson \& Reeb, 2003; Mishra et al., 2001). 
Meanwhile, ROE is accounts as another significant financial measure to evaluate firm performance. From the table, family ownership indicates lower valuation on average value of return on equity than non-family. The average value of return on equity for family and non-family is 0.3327 versus 0.3692 respectively.

For corporate governance mechanisms, board composition and board size are considered as control variables. In term of board composition, approximate 86 percent of these family and non-family ownership banks fulfil the requirement and the recommendation of the Malaysia Code on Corporate Governance (MCCG) 2000 that require at least minimum one third of the board involve outside directors. On average, the proportion of independent non-executive directors has represents 44.83 percent of total domination insiders on the board composition in Malaysia. This result interpret that average proportion of outside directors on the board is higher for non-family than family ownership. The mean value indicates 52.74 percent contribute by non-family whereas 46.16 percent account for family ownership respectively.

For board size characteristic, it presents similar average of minimum 8 persons of directors on board across all samples. This result is similar based on empirical studies carried out by Abdul Rahman and Mohamed Ali (2006); Haniffa and Hudaib (2006), the average board size is eight directors on board which is applicable either family or non-family ownership. This number of board size is consider appropriate and impact on board effectiveness that recommended by Jensen (1993). As overall, the result shows that minimum of board size is 7 members whereas the maximum is 14 members. However, the average mean does not indicate big difference between family and non-family ownership. The results show the approximate average of 10 directors for family ownership and 9 directors for non-family ownership respectively.

\subsection{Pearson's Correlation Matrix}

Table 4. Pearson's correlation matrix

\begin{tabular}{lllllll}
\hline Variables & Tobin's Q & ROA & ROE & Board Composition & Board Size & Ownership \\
\hline Tobin's Q & 1 & $\mathbf{- 0 . 3 8 1 * *}$ & $\mathbf{0 . 5 8 1 * *}$ & 0.059 & $\mathbf{- 0 . 2 2 6 *}$ & $\mathbf{- 0 . 3 8 4 * *}$ \\
ROA & & 1 & 0.139 & -0.009 & 0.098 & 0.146 \\
ROE & & & 1 & 0.061 & -0.068 & 0.123 \\
Board Composition & & & & 1 & $-\mathbf{0 . 4 4 4 * *}$ & $\mathbf{- 0 . 2 1 3 *}$ \\
Board Size & & & & 1 & $\mathbf{0 . 2 0 9 *}$ \\
Ownership & & & & & 1 \\
\hline
\end{tabular}

**Correlation is significant at the 0.01 level (2-tailed)

*Correlation is significant at the 0.05 level (2-tailed)

Table 4 represents the Pearson's Correlation Matrix that indicates the correlation coefficient for the dependent and independent variables of the study. In statistics standpoint, the Pearson's Correlation Matrix or sometimes called as Pearson product-moment correlation coefficient is computes to test the relationship of correlation between two variables. As demonstrated, Tobin's Q is a market measure of firm performance positively significant correlated to return on equity (ROE). In this standpoint, the movement of market share performance always consistent with maximizing shareholder wealth of a company. However, Tobin's Q performs negatively significant relationship with return on assets (ROA) and board size.

With regard profitability aspect, two major of financial measurement such as return on assets (ROA) and return on equity (ROE) are used to evaluate firm performance. There is a mixed results either positive or negative significant and insignificant relationship between the variables. For return on assets (ROA), results show positively correlated with return on equity (ROE) and board size respectively. However, there is a negatively correlation between return on assets (ROA) and board composition. In other words, board composition does not influence the return on assets (ROA) of a company due to possible less control power of outside directors on the board.

In contrast, return on equity (ROE) shows positively correlated with board composition and ownership structure. The positive coefficient indicates 6.1 percent correlated between return on equity and board composition. This is because the directors on the board usually concern about their return on investment. However, there show a negative correlated between return on equity (ROE) and board size with 6.8 percent. 
With regard corporate governance mechanism, board composition and board size used as control variables to determine firm performance. Board composition indicates negatively significant correlated with board size with 44.4 percent. Meanwhile, board composition indicates negatively significant correlated with ownership structure as well with 21.3 percent. Last but not least, board size displays positively significant correlated with ownership structure. In other words, board size does influence the performance of ownership structure.

4.3 Regression Analysis

Table 5. Regression results of family and non-family ownership and firm performance by using Tobin's Q

\begin{tabular}{lllll}
\hline Variables & & Full Sample & Family & Non-Family \\
\hline Constant & t-value & $(11.270)$ & $(4.976)$ & $(59.107)$ \\
Board Composition & Coefficient & -0.107 & -0.188 & -0.349 \\
& t-value & $(-0.971)$ & $(-0.996)$ & $(-2.518)$ \\
Board Size & Coefficient & -0.197 & -0.323 & -0.397 \\
& t-value & $(-1.795)$ & $(-1.713)$ & $(-2.863)$ \\
Observation & & 90 & 40 & 50 \\
$\mathrm{R}^{2}$ & & 0.179 & 0.074 & 0.190 \\
Adjusted R & & 0.150 & 0.024 & 0.156 \\
F statistics & & 6.247 & 1.470 & 5.528 \\
p-value & & 0.001 & 0.234 & 0.007 \\
\hline
\end{tabular}

Note: Adjusted $\mathrm{R}^{2}$ is the adjusted regression coefficient determinations

F-statistics is the indicate on how much variation is explain by regression equation

Table 6. Regression results of family and non-family ownership and firm performance by using ROA

\begin{tabular}{lllll}
\hline Variables & & Full Sample & Family & Non-Family \\
\hline Constant & t-value & $(0.002)$ & $(-0.138)$ & $(1.405)$ \\
Board Composition & Coefficient & 0.064 & 0.090 & 0.106 \\
& t-value & $(0.531)$ & $(0.459)$ & $(0.720)$ \\
Board Size & Coefficient & 0.097 & 0.108 & 0.305 \\
& t-value & $(0.813)$ & $(0.551)$ & $(2.071)$ \\
Observation & & 90 & 40 & 50 \\
$\mathrm{R}^{2}$ & & 0.029 & 0.009 & 0.084 \\
Adjusted $\mathrm{R}^{2}$ & & -0.005 & -0.044 & 0.045 \\
F statistics & & 0.866 & 0.170 & 2.146 \\
p-value & & 0.462 & 0.844 & 0.128 \\
\hline
\end{tabular}

Note: Adjusted $\mathrm{R}^{2}$ is the adjusted regression coefficient determinations

F-statistics is the indicate on how much variation is explain by regression equation 
Table 7. Regression results of family and non-family ownership and firm performance by using ROE

\begin{tabular}{lllll}
\hline Variables & & Full Sample & Family & Non-Family \\
\hline Constant & t-value & $(2.975)$ & $(2.828)$ & $(1.598)$ \\
Board Composition & Coefficient & 0.022 & -0.159 & 0.129 \\
& t-value & $(0.179)$ & $(-0.843)$ & $(0.852)$ \\
Board Size & Coefficient & -0.035 & -0.321 & 0.202 \\
& t-value & $(-0.290)$ & $(-1.700)$ & $(1.342)$ \\
Observation & & 90 & 40 & 50 \\
$\mathrm{R}^{2}$ & & 0.017 & 0.073 & 0.041 \\
Adjusted $\mathrm{R}^{2}$ & & -0.017 & 0.023 & 0.000 \\
F statistics & & 0.504 & 1.449 & 1.000 \\
$\mathrm{p}$-value & & 0.680 & 0.248 & 0.376 \\
\hline
\end{tabular}

Note: Adjusted $\mathrm{R}^{2}$ is the adjusted regression coefficient determinations

F-statistics is the indicate on how much variation is explain by regression equation

From the regression results as shown above (Table 5,6 and 7), it indicates that Tobin's $Q$ is the best fit as the dependent variable for the model. The Tobin's $Q$ regression model has the highest $F$ statistics value which is 6.247 as compared to ROA and ROE for full sample. Meanwhile, the adjusted R squared of Tobin's Q indicates similar higher value as well that is 0.150 between the dependent variables. The smaller value of $F$ statistics and adjusted R squared value usually explain other possible factors could influence the variation level of firm performance.

According to individual of family and non-family ownership alone, these two groups of ownership show negative relationship between board size and Tobin's Q or board size and ROE. The findings indicate that smaller board size could perform superior performance to the firms. This result is consistent with prior studies carried out by Mishra et al. (2001) and Yermack (1996). The prior evidence reveals that family members able to manage effectively in smaller board size rather than large board as close relationship between directors able to achieve same objectives. On the other hand, both groups of family and non-family ownership are positively related between board size and ROA. In Malaysia, there is no any rule and guideline states that appropriate number of board members should presence on the board according to Malaysia Code on Corporate Governance (MCCG). Indeed, board size maybe adjusts or changes based on past performance of the firm as suggested by Gilson (1990); Hermalin and Weisbach (1988), and Teh, Azbaijani and Ong (2012).

With respect board composition, the study examines the relationship between outside directors and firm performance. Based on the results, family firm is negatively performed between proportion of independent directors and either Tobin's Q or ROE. The outcome of the results are consistent based on prior studies from Haniffa and Hudaib (2006), Weir et al. (2002), Daily and Dalton (1998), Hermalin and Weisbach (1991), Klein (1998) and Merhan (1995). Further, according to Hermalin and Weisbach (2003) and Bino and Tomar (2010)., a higher percentage of outside directors presence on the board may cause poor performance yet consider as a good decision making process related to CEO turnover and directors earnings. However, proportion of outside directors on the board is positively influence by ROA only. This indicates that presence of outside directors could stabilize and improve the efficiency of profitability of a firm.

In conclusion, the results indicate that board composition and board size are strong influence on family firm performance. Smaller board size on the board can help the firm achieve better performance in term of Tobin's Q and ROE. In contrast, board composition attains better performance in term of ROA rather than Tobin's Q and ROE.

\section{Conclusion}

The main objective of this paper is to examine relationship between family and non-family ownership and bank performance. The findings indicate family ownership is positively significant related with bank performance. The results reveals that family ownership tends to perform better when measure by using ROE but slightly lower for Tobin's $Q$ if compared than non-family. This probably because of family ownership able to maintain consistent performance throughout each individual year. In addition, family members are likely to protect their 
family reputation in order to maximize shareholder wealth through good investment decision.

In contrast, the results reveal a strong relationship between board size and firm performance. Small board size able to improve family ownership performance rather than non-family ownership. With regard to board composition, proportion of outside directors show significant relationship in both family and non-family ownership. Family ownership does not significant improve the firm performance with the presence of outside directors whereas non-family requires more independent directors to reduce agency problem.

In conclusion, family ownership is more valuable as well as non-family ownership. These results prove that different governance mechanisms practice in family and non-family ownership are important to achieve superior performance.

\section{References}

Ab Razak, N. H., Ahmad, R., \& Joher, A. H. (2011). Does Government Linked Companies (GLCs) perform better than non-GLCs? Evidence from Malaysian listed companies. Journal of Applied Finance \& Banking, 213-240.

Abdullah, F., Shah, A., Iqbal, A. M., \& Gohar, R. (2011). The Effect of Group and Family Ownership on Firm Performance: Empirical Evidence from Pakistan. International Review of Business Research Papers, 177-194.

Amoor, T. (1995). Taking the heat in the economy's engine room, Sunday Telegraph 15 October, 14.

Amran, N. A. (2010). Corporate Governance Mechanism and Firm Performance: Evidence from Malaysian Companies.

Amran, N. A., \& Ahmad, A. C. (2009). Corporate Governance and Performance: Case of Family and Non-Family Companies in Malaysia.

Anderson, R., \& Reeb, D. (2003). Founding family ownership and performance. Evidence from the S\&P 500. Journal of Finance, 59, 1301-1327. http://dx.doi.org/10.1111/1540-6261.00567

Barry, T. A., Dacanay III, S. J., Lepetit, L., \& Tarazi, A. (2008). Ownership Structure And Bank Efficency In The Asia Pacific Region. European Commission ASIA-LINK project B7-3010/2005, 105-139.

Bino, A., \& Tomar, S. (2010). Corporate Governance and Bank Performance: Evidence from Jordanian Banking Industry.

Caers, R., Bois, C. D., Jegers, M., Gieter, S. D., Schepers, C., \& Pepermans, R. (2006). Principal-Agent Relationships on the Stewardship-Agency Axis. Journal of Nonprofit Management and Leadership, 17(1). http://dx.doi.org/10.1002/nml.129

$\mathrm{Chu}, \mathrm{W}$. (2009). The influence of family ownership on SME performance: evidence from public firms in Taiwan. Small Business Economics, 353-373. http://dx.doi.org/10.1007/s11187-009-9178-6

$\mathrm{Chu}$, W. (2011). Family ownership and firm performance: Influence of family management, family control and firm size. Asia Pacific Journal Management, 833-851. http://dx.doi.org/10.1007/s10490-009-9180-1

Donckels, R., \& Frohilch, E. (1991). Are family businesses really different? Eruopean experiences from STRATOS. Family Business Review, 7, 149-160. http://dx.doi.org/10.1111/j.1741-6248.1991.00149.x

Drobetz, W. (2009). The Impact of Coporate Governance on Firm Performance.

Faccio, M., Lang, L., \& Young, L. (2001). Dividends and expropriation. American Economic Review, 91, 54-78. http://dx.doi.org/10.1257/aer.91.1.54

Fama, E., \& Jensen, M. (1985). Organizational forms and investment decisions. Journal of Financial Economics, 14, 101-119. http://dx.doi.org/10.1016/0304-405X(85)90045-5

Fazlzadeh, A., Hendi, A. T., \& Mahboubi, K. (2011). The Examination of the Effect of Ownership Structure on Firm Performance in Listed Firms of Tehran Stock Exchange Based on the Type of the Industry. International Journal of Business and Management.

Hashim, H. A. (2011). Corporate Disclosure bt Family Firms: Malaysia Evidence. Journal of Business and Policy Research, 111-125.

He, E., \& Sommer, D. W. (2008). Separation of Ownership and Control: Implications for Board Composition. Journal of Risk and Insurance. 
Htay, S. N., Ab. Rashid, H. M., Adnan, M. A., \& Mydin Meera, A. K. (2011). Corporate Governance and Risk Management Information Disclosure in Malaysian Listed Banks: Panel Data Analysis. International Review of Business Research Papers, 159-176.

Ibrahim, H., \& Samad, F. A. (2010). Corporate Governance And Agency Costs: Evidence From Public Listed Family Firms in Malaysia.

Ibrahim, H., \& Samad, F. A. (2010). Family business in emerging markets: The case of Malaysia. African Journal of Business Management, 2586-2595.

Ibrahim, H., \& Samad, F. A. (2011). Corporate Governance Mechanisms and Performance of Public-Listed Family Ownership in Malaysia. International Journal of Economics and Finance.

Ibrahim, H., Samad, M. A., \& Amir, A. (2008). Board Structure and Corporate Performance: Evidence from Public-Listed Family-Ownership in Malaysia. Social Science Research Network.

Jensen, M. C., \& Meckling, W. H. (1976). Theory of the Firm: Managerial Behavior, Agency Costs and $\begin{array}{llll}\text { Ownership Structure. Journal of Financial Economics, 305-360. } & \text {. }\end{array}$ http://dx.doi.org/10.1016/0304-405X(76)90026-X

Kansikas, J., Tourunen, K., \& Laaksonen, S. (2011). Family influence on firm performance: Finnish publicly held family firm perspective. International Journal Entrepreneurship and Innovation Management, 48-61. http://dx.doi.org/10.1504/IJEIM.2011.038447

Kanthapanit, C., Armstrong, A., \& Tippet, J. (2011). Determinants of Minority Shareholder Rights in the Thai Banking Sector. World Review of Business Research, 90-102.

Kim, P. K., \& Rasiah, D. (2010). Relationship between Corporate Governance and Bank Performance in Malaysia during Pre and Post Asian Financial Crisis. Euopean Journal of Economics, Finance and Administrative Sciences, (21).

La Porta, R., Lopez-de-Silanes, F., \& Shleifer, A. (1990). Corporate ownership around the world. Journal of Finance, 54, 471-517. http://dx.doi.org/10.1111/0022-1082.00115

Lin, X., \& Zhang, Y. (2008). Bank Ownership Reform and Bank Performance in China. Journal of Banking \& Finance.

Martinez, J. I., Stohr, B. S., \& Quiroga, B. F. (2007). Family Ownership and Firm Performance: Evidence from public companies $\mathrm{n}$ Chile. Family Business Review, 20(2), 83-94. http://dx.doi.org/10.1111/j.1741-6248.2007.00087.x

Maury, B. (2006). Family Ownership and Firm Performance: Empirical Evidence from Western European Corporations. Journal of Corporate Finance, 321-341. http://dx.doi.org/10.1016/j.jcorpfin.2005.02.002

Mohd Abbas, S. Z., Abdul Rahman, R., \& Mahenthiran, S. (2009). Ultimate Ownership and Performance of Islamic Financial Institutions in Malaysia. Asian Finance Association Conference. Social Science Research Network.

Mohd Ghazali, N. (2010). Ownership Structure, Corporate Governance and Corporate Performance in Malaysia. International Journal of Commerce and Management, 109-119. http://dx.doi.org/10.1108/10569211011057245

Mohd Noor, M., \& Fadzil, D. H. (2011). Influence of Corporate Governance Attributes on Firms' Financial Performance in Malaysia. Annual Summit on Business and Entrepreneurial Studies ASBES 2011 Proceeding.

Mokhtar et al. (2009). Corporate Governance Practices and Firms Performance: The Malaysia Case. Journal of Money, Investment and Banking.

Morck, R., \& Yeung, B. (2004). Special Issues Relating to Corporate Governance and Family Control. World Bank Policy Research Working Paper 3406.

Najid, N. A., \& Rahman, R. A. (2011). Government Ownership and Performance of Malaysian Government-Linked Companies. International Research Journal of Finance and Economics, (61).

Ong, T. S, Teo, C. L., \& Teh, B. H. (2011). Analysis on Financial Performance And Efficiency Changes Of Malaysian Commercial Banks After Mergers And Acquisitions. International Journal of Business and Management Tomorrow, 1(2), 1-16. 
Pindado, J., Requejo, I., \& Torre, C. D. (2010). Do family firms outperform non-family ones? A panel date analysis of Western European corporations. Spain: Research agency of the Spanish Government, DGI and Regional Government of Castilla y Leon.

Sacristan-Navarro, M., Gomez-Anson, S., \& Cabeza-Garcia, L. (2011). Family Ownership and Control, the Presence of Other Large Shareholders, and Firm Performance: Further Evidence. Family Business Review, 71-93. http://dx.doi.org/10.1177/0894486510396705

San, O. T., \& Heng, T. B. (2011). Capital Structure and Corporate Performance of Malaysian Construction Sector. International Journal of Humanities and Social Science.

Shelash Al-Hawary, S. (2011). The Effect of Bank Governance on Banking Performance of The Jordanian Commercial Banks: Torbin's Q Model "An Applied Study". International Research Journal of Finance and Economics, (71).

Taboada, A. G. (2011). The impact of changes in bank ownership structure on the allocation of capital: International evidence. Journal of Banking \& Finance, 2528-2543. http://dx.doi.org/10.1016/j.jbankfin.2011.02.017

Teh, B. H., Azbaijani, S., \& Ong, T. S. (2012). Board of Directors and Capital Structure: Evidence from Leading Malaysian Companies. Asian Social Science, 8(3), 123-136.

Ting, P. H. (2011). The determinanats of board size and composition: Evidence from Taiwan banks. African Journal of Business Management, 7622-7631.

Villalonga, B., \& Amit, R. (2006). How do family ownership, control and management affect firm value? Journal of Financial Economics, 385-417. http://dx.doi.org/10.1016/j.jfineco.2004.12.005

Wen, W. (2010). Ownership Structure and Banking Performance: New Evidence in China. European Doctoral Programme in Entrepreneurship and Small Business Management.

Westhead, P., \& Cowling, M., (1997). Performance contrasts between family and non-family unquoted companies in the UK. Behaviour \& Research, 3(1), 30-52.

\section{Copyrights}

Copyright for this article is retained by the author(s), with first publication rights granted to the journal.

This is an open-access article distributed under the terms and conditions of the Creative Commons Attribution license (http://creativecommons.org/licenses/by/3.0/). 